DOI 10.15290/cnisk.2018.01.05.03

MGR EDYTA SACHAREWICZ

orcid.org/0000-0002-4069-2975

Uniwersytet w Białymstoku

\title{
Ciche bohaterki walki o niepodległość Senegalu
}

\section{Streszczenie}

W Senegalu okres kolonizacji francuskiej pogłębił różnice między mężczyzną a kobieta, która musiała stawić czoła wielu formom dyskryminacji. W konsekwencji została całkowicie wyeliminowana $z$ życia publicznego. Po odzyskaniu niepodległości jej sytuacja niewiele się zmieniła. Musiała dalej walczyć o lepsze prawa. Autorka niniejszego artykułu przedstawia działalność Senegalek w czasach kolonizacji francuskiej, jak i po odzyskaniu niepodległości, która miała poprawić ich sytuację w kraju oraz zwrócić uwage na problemy, z którymi musiały się zmagać na co dzień.

Słowa kluczowe: niepodległość, Senegal, kobiety, kolonizacja francuska, walka o prawa

\section{QUIET HEROINES OF THE FIGHT FOR INDEPENDENCE IN SENEGAL}

\begin{abstract}
In Senegal, the French colonization depended the inequality between man and woman facing many forms of discrimination. In consequence, she has been completely eliminated from public life. After regaining independence, her situation did not changed significantly. She had to continue fighting for better rights. The author of this article presents the activity of Senegalese women during the French colonization and after regaining independence, which was to improve their situation
\end{abstract}


in the country, and also to points out to the problems that they had to overcome everyday.

Keywords: independence, Senegal, women, French colonization, fight for rights

\section{Okres kolonialny}

Pierwsze próby penetracji francuskiej na terenach Senegalu datuje się na XVII stulecie. W 1659 r. Francja wkroczyła do miejscowości Ndar, zmieniajacc samowolnie jej nazwę na Saint-Louis, na cześć panującego wówczas we Francji Ludwika XIV. Normandzka spółka handlowa założyła tam ufortyfikowana osadę handlowa, narzucając miejscowej ludności hegemonię handlową, o którą od dziesiątków lat starali się inni Europejczycy: najpierw Portugalczycy, a następnie Holendrzy i Anglicy. Wkrótce Francuzi założyli nowe kolonie wzdłuż rzeki Senegal, a przede wszystkim opanowali tereny położone bardziej na południe: wyspę Gorée, Joal, Portudal, Rufisque ${ }^{1}$. Jak pisze jednak Łukasz Jakubiak,

o pełnej kolonizacji terytorium dzisiejszego Senegalu można mówić dopiero w odniesieniu do wieku XIX. Ekspansji wewnętrznej, skutkującej stłumieniem inspirowanego przez islamskich przywódców religijnych oporu rdzennej ludności tych terenów, dokonał Louis Faidherbe, który w 1854 r. objął urząd gubernatora kolonii, pełniąc tę funkcję ( $z$ dwuletnia przerwą w latach 1861-1863) do $1865 \mathrm{r}^{2}$

Zdobycie terytoriów Senegalu umożliwiło utworzenie w 1895 r. Francuskiej Afryki Zachodniej (Afrique Occidentale Française, AOF), w której skład oprócz Senegalu weszły także: Mauretania, Sudan Francuski (obecnie Mali), Gwinea Francuska (obecnie Gwinea), Wybrzeże Kości Słoniowej, Górna Wolta (obecnie Burkina Faso), Dahomej (obecnie Benin), Niger ${ }^{3}$. Przez blisko pół wieku, od powstania AOF do poczattków II wojny światowej, francuskie władze kolonialne były absolutnym panem sytuacji, a ich wszelkie plany i zarządzenia wymagały jedynie akceptacji $\mathrm{Pa}-$

\footnotetext{
1 B. Ndiaye, Kolonia Senegalu - poczatek kolonizacji francuskiej w Czarnej Afryce, „Echa Przeszłości" 2010, nr 11, s. 91.

2 Ł. Jakubiak, System ustrojowy Senegalu, Kraków 2014, s. 13.

3 B. Davidson, Społeczna i polityczna historia Afryki w XX wieku, przeł. B. Hlebowicz, Warszawa 2011, s. 131.
} 
ryża. Nowa władza stosowała system rządów bezpośrednich i nawet wodzowie wiosek czy też gmin wiejskich byli mianowani przez administrację kolonialna ${ }^{4}$. Bara Ndiaye podkreśla, iż oprócz eksploatacji ekonomicznej oraz asymilacji kulturowej ${ }^{5}$ Senegalczycy razem z innymi Afrykańczykami byli obowiazkowo wcielani do korpusu wojennego senegalskich strzelców (fr. Tirailleurs Senegalais) założonego przez Faidherbe’a w 1857 r. W jego szeregach Senegalczycy musieli walczyć po stronie francuskiej w różnego rodzaju konfliktach zbrojnych ${ }^{6}$.

Mimo wyzysku kolonialnego Senegalczycy mogli się cieszyć względnym spokojem, bez wojen plemiennych i religijnych, które wcześniej toczyły się na tych ziemiach niemal permanentnie. Dzięki kolonizacji powstała infrastruktura i kraje afrykańskie otrzymały język komunikacji międzynarodowej, co skutkowało utworzeniem pierwszej czarnoskórej elity.

\section{Kobiety $\mathbf{z}$ Walo}

Walo to królestwo w Afryce Zachodniej, które obejmowało terytoria $z$ dwóch stron rzeki Senegal i rozciagało się aż do Oceanu Atlantyckiego, na północy graniczyło $z$ państwem Maurów, na południu $z$ królestwem Kajor, na wschodzie zaś z królestwem Dżolof ${ }^{7}$. W ostatnich latach istnienia władza w nim należała do kobiet, Ndjeumbeut Mbodj oraz Ndaté Yalla Mbodj, córek królowej Fatim Yamar Khouryaye Mbodj, która zginęła w heroicznej walce przeciw Maurom Trarza ${ }^{8}$. Po śmierci

\footnotetext{
4 Z. Komorowski, Senegal kształtowanie sie jedności oraz niepodległości, Warszawa 1977, s. 54.

5 Asymilacja (fr. assimilation, la) - polityka postępowania wobec mniejszości narodowych, polegająca na narzucaniu norm kulturowych. Dzieli się na wewnętrzną (odbywająca się w państwie, do którego przyjeżdżają imigranci) oraz zewnętrzną (uprawianą przez państwo ekspansywne, na zajętym terytorium). Historycznym przykładem asymilacji zewnętrznej są kolonie, których ludność asymilowano przy użyciu narzędzi propagandowych, jak np. administracja, szkolnictwo, armia, misje (A. Włoczewska, Mały leksykon pojęć i terminów frankofońskich, Białystok 2012, s. 56).

6 B. Ndiaye, Senegal: krótki rys historyczny [online], [Dostęp: 28.12.2017]. Dostępny w World Wide Web: http://bit.ly/2lbcwhK.

7 Idem, Kolonia Senegalu..., op. cit., s. 100.

87 marca 1820 r. Fatim Yamar Khouriaye wraz z innymi kobietami pod nieobecność mężczyzn, którzy pracowali w polu, stawiła czoła wrogowi, który napadł na stolicę królestwa. Widząc, iż nie mają szans $z$ oddziałami mężczyzn, Fatim Yamar Khouriaye wolała spłonąć żywcem niż zginąć $\mathrm{z}$ rąk wroga. Tamtego dnia udało jej się jedynie ewakuować dwie córki, Ndjeumbeut Mbodj oraz Ndaté Yalla Mbodj, dzięki którym królestwo miało przetrwać (F. Sarr, Féminismes en Afrique occidentale? Prise de conscience et luttes
} 
matki władzę w królestwie objęła starsza z sióstr, Ndjeumbeut Mbodj, a następnie, w 1846 r., Ndaté Yalla, która była ostatnią władczynią Walo. Mówiono o niej, że jest silna, inteligentną oraz piękną kobietą. Rządziła żelazna ręka, nie bojąc się otwarcie zamanifestować swojego sprzeciwu wobec władzy kolonialnej w Afryce Zachodniej. W 1847 r. nie zgodziła się, by bydło, które miało dotrzeć do Saint-Louis, przeszło przez jej ziemie, a 5 listopada 1850 r. zakazała całkowitego handlu w strefie jej wpływów. Takie działania godziły w interesy Francuzów, w których potęgowała nienawiść. Ostatecznie w lutym 1855 r. oddziały francuskie dowodzone przez Faidherbe'a pokonały królowa Ndaté Yalla oraz jej ludzi. Przegrana bitwa wyznaczyła kolejny etap podboju Senegalu przez Francuzów9 ${ }^{9}$ Historia królestwa Walo pokazuje, iż pierwsza forma oporu, na jaką napotkali Francuzi w swojej polityce kolonialnej, była zorganizowana przez kobietę, co świadczy o sile i odwadze tzw. słabszej płci.

\section{Sytuacja kobiet w czasach kolonizacji francuskiej}

W czasach kolonizacji francuskiej mieszkanki Senegalu musiały stawić czoła wielu formom dyskryminacji. Ich sytuacja była o wiele gorsza niż mężczyzn, właśnie ze względu na płeć. Nowa władza mająca własne tradycje, religię, przekonania chciała narzucić podbitemu ludowi system patriarchalny, w którym kobieta zostaje całkowicie wykluczona ze sfery publicznej. Jak zauważyła Ania Loomba:

Kolonializm doprowadził do erozji wielu matrylinearnych czy „przyjaznych kobietom" kultur i praktyk bądź też zintensyfikował podporzadkowanie kobiet na skolonizowanych terytoriach. Na afrykańskiej wsi handel niewolnikami osłabił kontrolę, jaka kobiety uprzednio sprawowały nad uprawami i plonami. Gdy rolnictwo zaczęło podupadać, a męska siła robocza wyemigrowała do miast, kobiety stawały się coraz bardziej ekonomicznie zależne od dochodów mężczyzn. Również chrześcijaństwo dokonało poważnych zmian w strukturach rodzinnych i wzorcach seksualnych. (...) Kolonializm cementował patriarchalny ucisk często dlatego, że rdzenni mężczyźni - coraz bardziej pozbawiani

politiques et sociales [w:] Vents d'Est, vents d'Ouest: Mouvements de femmes et féminismes anticoloniaux, red. Ch. Verschuur, Genève 2009, s. 83).

9 M. Ndiaye, Le digne héritier de la Royauté du Walo [online], [Dostęp: 18.12.2017]. Dostępny w World Wide Web: <http://bit.ly/2jdDt2X> 
praw obywatelskich i wyłączani ze sfery publicznej - stawali się większymi tyranami w sferze domowej. Traktowali dom i kobietę jako desygnaty kultury i narodowości. Świat zewnętrzny mógł być zwesternizowany, ale nie wszystko było stracone dopóty, dopóki przestrzeń domowa zachowywała kulturową czystość ${ }^{10}$.

To właśnie model kolonialny pogłębił różnice między obiema płciami. W konsekwencji Senegalki zostały pozbawione prawa do edukacji ${ }^{11}$ czy własności prywatnej ${ }^{12}$, miały się podporządkować rozkazom kolonizatora oraz swojemu mężowi. W nowej rzeczywistości Afrykanka - jako przedstawicielka słabszej oraz gorszej płci - zajmowała najniższa pozycję w hierarchii społecznej ${ }^{13}$.

Wpływ Francji na życie kobiet był najbardziej dotkliwy w dziedzinie ekonomii i prawa - na tych właśnie polach Senegalki musiały stoczyć najwięcej „bitew”. W tamtych czasach, pozbawione wszelkich praw wyborczych, nie miały innej możliwości, jak tylko zasilić szeregi partii politycznych utworzonych przez mężczyzn ${ }^{14}$ : Section Française de 1'Internationale Ouvrière (Francuska Sekcja Międzynarodówki Robotniczej, SFIO) czy Rassemblement Démocratique Africain (Afrykańskie Zrzeszenie Demokratyczne, RDA). U boku mężczyzn walczyły z niesprawiedliwością, ograniczeniami, nieludzkimi warunkami życia narzuconymi przez kolonizatora. Uwage zwraca jednak fakt, iż w głównej mierze w szeregach partii pełniły one niemniej ważną funkcję animatorek wieców wyborczych najważniejszych działaczy politycznych tamtych czasów: Lamine'a Guèye, Blaise'a Diagne ${ }^{15}$ czy Galandou Dioufa. Dzięki ich zdolności do mobilizacji politykom udawało się przykuć uwagę większej liczby potencjalnych wyborców. Podczas różnego rodzaju manifestacji

\footnotetext{
10 A. Loomba, Kolonializm. Postkolonializm, przeł. N. Bloch, Poznań 2011, s. 178-179.

11 W latach 1919-1920 zaledwie jedna dziewczynka na 45 chłopców chodziła do szkoły (P. Barthélémy, La formation des Africaines à l'École normale d'institutrices de l'AOF de 1938 à 1958. Instruction ou Éducation?, „Cahiers d’Études Africaines” 2003, nr 169/170, s. 372).

12 Na podstawie Kodeksu Napoleona, który obowiązywał we Francji od 1804 r., cały majątek należał do głowy rodziny, czyli mężczyzny (F. Sarr, op. cit., s. 87).

13 Ibidem.

14 H. Djibo, La participation des femmes africaines à la vie politique, Paris 2001, s. 88.

15 Blaise Diagne - senegalski polityk, założyciel Parti socialiste sénégalais (Senegalskej Partii Socjalistycznej), był pierwszym Afrykaninem wybranym do francuskiego Zgromadzenia Narodowego (Z. Komorowski, op. cit., s. 56).
} 
politycznych czy też kulturalnych ubrane w kolory partii, do których należały, wzbudzały duże zainteresowanie:

Z okazji święta narodowego 14 lipca 1936 r. tłumy kobiet podkreślały swoje zdolności do organizowania manifestacji o ludowym zabarwieniu; ubrane w obszerne zielone boubou [rodzaj wierzchniego odzienia, długiej i obszernej sukni], czerwoną chustkę na głowie, machały małymi czerwonymi flagami, robiły wrażenie ${ }^{16}$.

Byłoby jednak wielce niesprawiedliwe, gdyby ich działalność została ograniczona jedynie do organizacji manifestacji politycznych o zabarwieniu folklorystycznym. Jak zauważa Renata Diaz-Szmidt: kobiety walczyły $z$ kolonialna przemoca dyskursywna, a także fizyczna jako partyzantki, łaczniczki, pielegniarki i narażały życie $w$ czasie krwawych batalii17. Warto wspomnieć, iż w październiku 1947 r. kobiety brały czynny udział w strajku kolei Dakar-Niger, wspierając mężów i braci, dowodząc własnej odwagi oraz gotowości do wielkich poświęceń dla dobra kraju ${ }^{18}$.

Walka o niepodległość kraju nie była jedyna, jaką musiały toczyć w czasach kolonizacji. Gdy 19 lutego 1945 r. Francuzi przyznali prawo do głosowania tylko Francuzkom, które zamieszkiwały terytoria kolonialne, odmawiajac przyznania tego samego prawa rdzennym mieszkankom regionu, Senegalki, które szybko zmobilizowały swoje siły, wyszły na ulice Dakaru i Saint-Louis, by otwarcie zamanifestować niezadowolenie. Walka o równe prawa była wspierana również przez senegalskich polityków, którzy byli świadomi korzyści, jakie może im przynieść elektorat kobiecy. W przypadku wykluczenia Senegalek nawoływano do blokowania ulic w dniu wyborów, a nawet do aktów przemocy. Wobec skali protestu minister kolonii musiał ustapić, przyznając Senegalkom 6 lipca 1945 r. takie samo prawo wyborcze ${ }^{19}$.

Ostatecznie, by wspomóc w działalności politycznej swoich mężów oraz braci szykanowanych przez kolonialna władzę, zdecydowały się one na utworzenie w 1954 r. Union des Femmes Sénégalaises (Unia Senegalskich Kobiet, UFS), jednej z głównych organizacji kobiecych powstałej w czasach kolonizacji francuskiej. Członkinie partii otwarcie deklarowały swoja apolityczność, nie przeszkadzało im to jednak podażać za swoimi

16 B. Traoré [w:] H. Djibo, op. cit., s. 89.

17 R. Diaz-Szmidt, Nurty feminizmu afrykańskiego, „Afryka” 2013, nr 38, s. 59.

18 H. Djibo, op. cit., s. 90.

19 N.S. Guèye, Mouvements sociaux des femmes au Sénégal, Dakar 2013, s. 50. 
ideałami i głosić hasła: „Niepodległość przede wszystkim”. Zajmowały się dystrybucją ulotek oraz plakatów, uczestniczyły we wszystkich ważnych wydarzeniach dotyczacych spraw kraju, manifestowały też swoje niezadowolenie wobec polityki generała de Gaulle'a ${ }^{20}$, który w 1958 r. odwiedził Senegal, należały do Comité de défense des libertés démocratiques (Komitet Obrony Wolności Demokratycznych), który 22 maja został utworzony w Dakarze, poruszały kwestie dotyczace praw kobiet i jako pierwsze w Senegalu 8 marca 1954 r. uczciły Międzynarodowy Dzień Kobiet ${ }^{21}$.

Począwszy od 1959 r., możemy obserwować rozpad UFS. Powodów takiej sytuacji było kilka, m.in. odejście jednej z czołowych działaczek Jeanne Martin Cissé22, sekretarz generalnej, która wróciła do Gwinei, oraz konflikty wewnątrz partii, do których należały członkinie UFS. Mimo wszystko był to dla wielu Afrykanek ważny okres w ich działalności, gdyż pozwolił im zdobyć doświadczenie w zakresie polityki ${ }^{23}$.

\footnotetext{
${ }^{20}$ Wobec narastającego zagrożenia utraty władzy we Francuskiej Afryce Zachodniej de Gaulle zgodził się na samodzielne rządy 12 kolonii, przekonując, iż wszystkie powinny być ze sobą związane w ramach nowej unii Communauté Française (Wspólnota Francuska). Każda $z$ kolonii posiadałaby szeroką władzę samorządowa, ale Francja pozostawałaby „macierza” w finansach, polityce zagranicznej i sprawach wojskowych. Każda miałaby własny parlament, rząd, flagę i hymn narodowy, ale w ważnych sprawach decydujący głos należałby do Francji. By wyeliminować ewentualnych przeciwników swego planu, de Gaulle zaproponował referendum, w którym „tak" miało oznaczać zgodę na zaproponowane przez niego rozwiązanie, „nie” - opowiedzenie się za pełną niepodległością. Gdyby większość głosujacych odpowiedziała „nie”, Francja natychmiast wstrzymałaby wszelka pomoc dla kolonii. De Gaulle sam objeżdżał kolonie, zachęcając do głosowania za swoim planem. Ponieważ wszystkie kolonie były uzależnione od pomocy Francji, był pewien, że wszystkie wybiora właśnie to rozwiązanie (B. Davidson, op. cit., s. 130-131).

21 F. Sarr, Sénégal: forces et faiblesses de la dynamique des mouvements de femmes, „Alternatives Sud” 2015, nr 4, s. 108.

${ }_{22}$ Jean Martin Cissé - ur. 6 kwietnia 1926 r. w Kankan w Gwinei, zm. 21 lutego 2017 r. w Conkary, polityk, jedna z pierwszych gwinejskich nauczycielek, która ukończyła słynna Szkołę dla Nauczycielek w miejscowości Rufisque założoną przez francuskiego kolonizatora. W 1949 r. wraz z mężem Sékou Touré przeprowadziła się do Dakaru i szybko włączyła się w walkę o niepodległość oraz emancypację kobiet w Afryce. W 1972 r. jako pierwsza kobieta przewodniczyła Radzie Bezpieczeństwa ONZ. Pełniła również funkcję ministra za rządów Sékou Touré, który był pierwszym prezydentem Republiki Gwinejskiej w latach 1958-1984 (F.X. Freland, La Guinée endeuillée par la disparition de Jeanne Martin Cissé, figure de l'indépendance et des droits des femmes, [online], [Dostęp: 19.12.2017]. Dostępny w World Wide Web: <http://bit.ly/21KC6eI>).

${ }^{23}$ F. Sarr, Féminismes en Afrique..., op. cit., s. 90.
} 


\section{Odzyskanie niepodległości}

Prawdziwe zmiany w sytuacji kobiet w rodzinie, państwie i społeczeństwie Senegalu zaczęły się, gdy w 1960 r. kraj odzyskał niepodległość ${ }^{24}$. Pierwszy prezydent Léopold Sédar Senghor, rozumiejąc, iż państwo, w którym połowa jego mieszkańców jest wykluczona $z$ życia publicznego, nie może dobrze funkcjonować, rozpoczął reformy, które miały znieść obyczaje dyskryminujące kobiety. Rozumiał, że należy poprawić ich sytuację we wszystkich dziedzinach życia, dlatego też wprowadził liczne zmiany w prawodawstwie. Pierwsza główną reforma społeczna w Senegalu po uzyskaniu niepodległości było przyjęcie gwarantującej równouprawnienie konstytucji. Kobiety otrzymały prawo do pracy bez zgody męża. Przyjęty w 1972 r. Kodeks rodzinny określał najważniejsze prawa kobiet w życiu rodzinnym i społecznym, m.in. minimalny wiek zawarcia małżeństwa (dla kobiet 15 lat, dla mężczyzn 18 lat); dobrowolność zawierania małżeństw, tym samym zakazywał przedwczesnych lub przymusowych małżeństw; takie same procedury rozwodowe dla mężczyzn i kobiet wraz z możliwością otrzymania prawa do opieki nad dziećmi po rozwodzie (bez względu na wiek). $Z$ kolei Kodeks karny z 24 stycznia 1999 r. (wprowadzony już po zakończonej prezydenturze Senghora, który w 1980 r. dobrowolnie zrezygnował z zajmowanego stanowiska) mówił o karaniu wszelkiej formy przemocy wobec kobiet, włączając molestowanie seksualne, gwałt, okaleczenie ciała (obrzezanie) ${ }^{25}$.

Te głębokie zmiany nie sprawiły, iż przypadki naruszenia prawa, patologii rodzinnych czy przemocy zostały całkowicie wyeliminowane z senegalskiego społeczeństwa. Rzeczywistość pokazała, że prawdziwe równouprawnienie kobiet i mężczyzn to proces bardzo złożony i długotrwały. Również marginalizacja kobiet w życiu politycznym była dalej widoczna, o czym może świadczyć fakt, iż dopiero w 1963 r. w parlamencie senegalskim pojawiła się pierwsza kobieta posłanka, Caroline Faye Diop. $Z$ kolei w 1978 r. prezydent Senghor po raz pierwszy na stanowisko ministra w swoim rządzie powołał kobietę. Wspomniana Caroline Faye

${ }_{24}$ W 1960 r. wszystkie kolonie Francuskiej Afryki Zachodniej i Równikowej - Gabon, Kongo Francuskie (obecnie Republika Konga), Ubangi-Szari (obecnie Republika Środkowoafrykańska), Czad ( $z$ wyjątkiem niepodległej już od dwóch lat Gwinei) - a także powiernicze Kamerun i Togo, stały się republikami (B. Davidson, op. cit., s. 131).

25 I.A. Ndiaye, Kobieta $w$ Islamie. Na przykładzie Senegalu jako nowoczesnego kraju muzułmańskiego, „Forum Politologiczne” 2006, t. 4, s. 306-307. 
Diop pełniła funkcję sekretarza stanu ds. kobiet. Iwona Anna Ndiye w artykule Kobieta $w$ Islamie. Na przykładzie Senegalu jako nowoczesnego kraju muzułmańskiego komentuje:

Wprawdzie ta swoista promocja senegalskiej kobiety w kwestii awansu społecznego i politycznego na najważniejsze funkcje $\mathrm{w}$ państwie miała miejsce dopiero 18 lat po uzyskaniu niepodległości, jednakże jej znaczenie w procesie emancypacji kobiet trudno przecenić. Rozpoczał się etap stałego udziału kobiet w życiu politycznym. Do rządu weszły m.in. Maimouna Kane, Marie Sarr Modj, Mantoulaye Guène. 4 marca 2001 r. po raz pierwszy w historii Senegalu premierem rządu została kobieta - Mama Madiora Boye ${ }^{26}$.

Świadome marginalnej pozycji, która zajmowały w życiu publicznym, Senegalki zaczęły tworzyć różnego rodzaju stowarzyszenia, by móc wspólnie zając się problemami, które je trapiły. W konsekwencji w latach 19701990 możemy obserwować wzrost aktywności kobiet w sferze publicznej. Bez watpienia na taki rozwój sytuacji wpływał też fakt, iż w walkę o poprawę bytu zaangażowały się Afrykanki, które jeszcze w czasach kolonizacji francuskiej miały możliwość uczęszczania do szkół ${ }^{27}$. Edukacja, którą w tym czasie zdobyły, wpłynęła na ich życie, sposób postrzegania rzeczywistości oraz stanowiła pierwszy krok na drodze do zdobycia niezależności finansowej i intelektualnej. Kobiety, które stały się świadome siły, a także możliwości, jakie w nich drzemały, były zdolne do walki o lepsza pozycję w społeczeństwie afrykańskim. Jedną z nich była Annette Mbaye d'Erneville, dziennikarka, która stworzyła czasopismo „Femmes de Soleil". To czasopismo kobiece, którego nazwa w 1963 r. została zmieniona na „Awa”, poświęcone jest w głównej mierze modzie i urodzie, ale porusza również tematy dotyczące życia politycznego czy społecznego, zwracając uwagę na pozycję kobiety we współczesnym świecie ${ }^{28}$. Warto

\footnotetext{
26 Ibidem, s. 309.

27 W okresie międzywojennym kobiety miały możliwość zdobycia dyplomu położnej lub pielęgniarki w szkole medycznej, która mieściła się w Dakarze (w tej samej szkole kształcono również przyszłych lekarzy i farmaceutów), a od 1938 r. dyplomu nauczycielki w szkole dla nauczycielek otwartej w mieście Rufisque. Obie instytucje aż do 1960 r. były uznawane za najbardziej prestiżowe placówki edukacyjne, gwarantujące awans społeczny (P. Barthélémy, La professionnalisation des Africaines en AOF (1920-1960), „Vingtième Siècle. Revue d'Histoire" 2002, nr 75, s. 36).

28 „Awa” - oficjalna strona czasopisma [Dostęp: 27.12.2017]. Dostępny w World Wide Web: <http://bit.ly/2lpjfnf>.
} 
też wspomnieć, że w 1987 r. d'Erneville przyczyniła się do powstania Muzeum Kobiet, któremu nadano imię Henriette Bathily, słynnej działaczki społecznej i dziennikarki promującej senegalską kobietę w mediach i kulturze. Miejsce prezentuje historię najbardziej znanych kobiet w Senegalu, demonstrujących różnorodne dziedziny aktywności zawodowej oraz społecznej.

W 1974 r. powstało stowarzyszenie Amicale des femmes juristes sénégalaises, które jako jedno $z$ pierwszych zajęło się propagowaniem praw należących do kobiet. W 1977 r. Klub Soroptimist zorganizował seminarium dotyczące warunków życia Senegalek. To spotkanie skutkowało utworzeniem jednej $z$ najważniejszych organizacji zajmujących się obecnie sprawami kobiet w Senegalu, Federacji Stowarzyszeń Kobiet w Senegalu (FAFS). Jest to organizacja pozarządowa na rzecz rozwoju Afryki, która powstała też przy zaangażowaniu ze strony prezydenta Senghora. W momencie utworzenia należało do niej 13 stowarzyszeń działających w różnych sferach publicznych. Obecnie liczy około 20 tys. członków i grupuje 400 stowarzyszeń, $z$ których każde liczy przeciętnie 30 członków. Prezesem organizacji jest Abibatou Ndiaye. Wśród najważniejszych celów FAFS są: zjednoczenie stowarzyszeń kobiecych i stworzenie partnerskich relacji, działalność na rzecz emancypacji społecznej i zawodowej kobiety oraz jej rozwoju ekonomicznego, udział w walce $z$ analfabetyzmem, nędzą i suszą ${ }^{29}$.

Jedna $z$ ważniejszych organizacji kobiecych działających w latach 80. była Yewwu-Yewwi/PLF (Pour la libération des femmes), która powstała w 1984 r. Jej członkiniami w głównej mierze były kobiety wykształcone ${ }^{30}$ : nauczycielki, lekarki, prawniczki, dziennikarki, których poglądy szły w parze $z$ tymi głoszonymi przez afrykańskie ruchy feministyczne $^{31}$. Próbowały uwrażliwić społeczeństwo senegalskie na problemy

\footnotetext{
${ }_{29}$ Courants de femmes [Dostęp: 24.12.2017]. Dostępny w World Wide Web: <http://bit. ly/2BIrJkl>.

${ }_{30} \mathrm{~W}$ szeregach partii działali również mężczyźni, którym los kobiet nie był obojętny (N.S. Guèye, op. cit., s. 51).

31 Afrykanki uznaja, że walka o emancypację afrykańskich kobiet jest wspólną sprawą obu płci, a jej skutki będą dobre nie tylko dla kobiet, które zdobędą możliwość rozwijania własnych ambicji i realizowania marzeń, lecz także dla mężczyzn, gdyż działania na rzecz poprawy sytuacji kobiet zawsze są działaniami sprzyjającymi ogólnie pojętemu rozwojowi społecznemu, co skutkuje wyższym procentem świadomych i wykształconych obywateli. Feminizm afrykański jest zatem u swych podstaw utożsamiany $z$ działaniem na rzecz poprawy sytuacji kobiet nie tylko (choć przede wszystkim) przez nie same, lecz także przez mężczyzn (R. Dìaz-Szmidt, op. cit., s. 50).
} 
kobiet, które wynikały nie tylko $z$ nierównych praw dla obu płci, lecz także $z$ tradycji (wczesne zamążpójście, poligamia). Brały udział w licznych konferencjach, seminariach, ale również zaangażowały się w walkę o pokój w Casamance ${ }^{32}$.

Od momentu odzyskania niepodległości także rząd Senegalu podjął wiele inicjatyw, by zmniejszyć różnice w integracji między obiema płciami, m.in. zainicjowano Dni Kobiet, dwutygodniowy cykl imprez o charakterze edukacyjnym, rozrywkowym, kulturalnym. W dniach 27-29 grudnia 1982 r. w Dakarze odbyła się międzynarodowa konferencja kobiet, podczas której dyskutowano o problemach trapiących kobiety w Afryce: poligamia, analfabetyzm, okaleczenia seksualne. $Z$ pewnością rok 1975 , proklamowany Światowym Rokiem Kobiet, oraz ogłoszona przez ONZ Dekada Kobiet (1976-1985) przyniosły na arenie międzynarodowej przełom w postrzeganiu praw kobiet jako praw człowieka. W tym okresie odbyły się trzy $z$ czterech swiatowych konferencji ONZ dotyczacych sytuacji kobiet (Meksyk 1975 r., Kopenhaga 1980 r., Nairobi 1985 r.), które w znacznym stopniu przyczyniły się do wzmocnienia ruchów kobiecych ${ }^{33}$.

W Senegalu kolonializm zdecydowanie osłabił pozycję kobiet w społeczeństwie. Nie poddały się one jednak w pełni męskiej dominacji, stawiając czoła najeźdźcy. Analiza historyczna ukazuje, iż za każdym razem, zarówno w trakcie kolonizacji, jak i po odzyskaniu niepodległości, gdy tylko była taka potrzeba, Afrykanki potrafiły zjednoczyć siły, by walczyć o swoje prawa. Nierzadko lekceważone oraz niedoceniane, przeprowadziły „cichą rewolucje”, która ostatecznie w 2010 r. doprowadziła do uchwalenia ustawy, według której we wszystkich wybieralnych instytucjach państwowych (w tym także w obu izbach parlamentu) ma obowiązywać tzw. absolutny parytet płci.

\footnotetext{
${ }^{32}$ N.S. Guèye, op. cit., s. 51.

${ }_{33}$ Gender Indeks: monitorowanie równości kobiet i mężczyzn w miejscu pracy, red. E. Lisowska, Warszawa 2007, s. 13.
} 


\section{Bibliografia}

\section{Opracowania}

Barthélémy Pascale, La formation des Africaines à l'École normale d'institutrices de l'AOF de 1938 à 1958. Instruction ou Éducation?, „Cahiers d'Études Africaines” 2003, nr 169/170, s. 371-388, ISSN 1777-5353.

Barthélémy Pascale, La professionnalisation des Africaines en AOF (19201960), „Vingtième Siècle. Revue d'Histoire” 2002, nr 75, s. 35-46, DOI 10.3917/ving.075.0035.

Davidson Basil, Społeczna i polityczna historia Afryki w XX wieku, przeł. Bartosz Hlebowicz, Warszawa : Wydawnictwo Naukowe PWN, 2011, ISBN 978-83-01-16851-3.

Dìaz-Szmidt Renata, Nurty feminizmu afrykańskiego, „Afryka” 2013, nr 38, s. 51-72, ISSN 1234-0278.

Djibo Hadiza, La participation des femmes africaines à la vie politique, Paris : L'Harmattan, 2001, ISBN 2-7475-0330-5.

Gender Indeks: monitorowanie równości kobiet $i$ mężczyzn $w$ miejscu pracy, red. Ewa Lisowska, Warszawa : UNDP, EQUAL, 2007, ISBN 978-83917047-9-0.

Guèye Ndèye Sokhna, Mouvements sociaux des femmes au Sénégal, Dakar : Codesria, 2015, ISBN 978-2-86978-634-9.

Jakubiak Łukasz, System ustrojowy Senegalu, Kraków : Wydawnictwo Uniwersytetu Jagiellońskiego, 2014, ISBN 978-83-23337-584.

Komorowski Zygmunt, Senegal - kształtowanie sie jedności i niepodległości, Wyd. 1, Warszawa : Instytut Afrykanistyczny Uniwersytetu Warszawskiego, 1977.

Loomba Ania, Kolonializm. Postkolonializm, przeł. Natalia Bloch, Poznań : Wydawnictwo Poznańskie, 2011, ISBN 978-83-7177-758-5.

Ndiaye Bara, Kolonia Senegalu - poczatek kolonizacji francuskiej w Czarnej Afryce, „Echa Przeszłości” 2010, nr 11, s. 91-109, ISSN 1509-9873.

Ndiaye Iwona Anna, Kobieta w Islamie. Na przykładzie Senegalu jako nowoczesnego kraju muzulmańskiego, „Forum Politologiczne” 2006, t. 4, s. 303-322, ISSN 1734-1698.

Sarr Fatou, Féminismes en Afrique occidentale? Prise de conscience et luttes politiques et sociales [w:] Vents d'Est, vents d'Ouest: Mouvements de 
femmes et féminismes anticoloniaux, red. Christine Verschuur, Genève : Graduate Institute Publications, 2009, s. 83-100.

Sarr Fatou, Sénégal: forces et faiblesses de la dynamique des mouvements de femmes, „Alternatives Sud” 2015, nr 4, s. 107-114, ISSN: 1026-2253. Włoczewska Agnieszka, Mały leksykon pojęć i terminów frankofońskich, Białystok : Wydawnictwo UwB, 2012, ISBN 978-83-7431-318-6.

\section{Zasoby internetowe}

„Awa” - oficjalna strona czasopisma [Dostęp: 27.12.2017]. Dostępny w World Wide Web: <http://bit.ly/2lpjfnf>.

Courants de femmes [Dostęp: 24.12.2017]. Dostępny w World Wide Web: $<$ http://bit.ly/2BIrJkl>.

Freland François-Xavier, La Guinée endeuillée par la disparition de Jeanne Martin Cissé, figure de l'indépendance et des droits des femmes, [online], [Dostęp: 19.12.2017]. Dostępny w World Wide Web: <http://bit. ly/21KC6eI>.

Ndiaye Bara, Senegal: krótki rys historyczny [online]. [Dostęp: 28.12.2017]. Dostępny w World Wide Web: <http://bit.ly/2lbcwhK>.

Ndiaye Mously, Le digne héritier de la Royauté du Walo [online], [Dostęp: 18.12.2017]. Dostępny w World Wide Web: <http://bit.ly/2jdDt2X>. 